\title{
Phytoremediation of petroleum hydrocarbon using three mangrove species applied through tidal bioreactor
}

\author{
NURUL HIDAYATI, HAMIM HAMIM", YOHANA C. SULISTYANINGSIH \\ Department of Biology, Faculty of Mathematics and Natural Sciences, Institut Pertanian Bogor. Jl. Agathis, Kampus IPB Darmaga, Bogor 16680, West \\ Java, Indonesia. Tel.: +62-251-8625481, `email: hamim@ipb.ac.id; hamimhar@gmail.com
}

Manuscript received: 14 March 2018. Revision accepted: 9 April 2018.

\begin{abstract}
Hidayati N, Hamim H, Sulistyaningsih YC. 2018. Phytoremediation of petroleum hydrocarbon using three mangrove species applied through tidal bioreactor. Biodiversitas 19: 786-792. Mangrove is important component in coastal ecosystems that often faces environmental pollution including industrial waste, particularly oil waste (petroleum hydrocarbon). This study was aimed to analyze the growth, anatomical, and physiological responses of three mangroves species to petroleum hydrocarbon contaminant applied using tidal bioreactor (ebb flow system) as a model of sea-shore environmental condition. The experiment was carried out using completely randomized design with two factors i.e.: three species of mangrove (Rhizophora sp., Avicennia sp. and Bruguiera sp.) and four levels of petroleum concentration $(0 \%, 10 \%, 20 \%$ and $30 \%)$ exposed using tidal bioreactor for 30 days. The parameters observed in this experiment were plant viability, total petroleum hydrocarbon (TPH) of media, plant growth, $\mathrm{pH}$ of media and roots malondialdehyde (MDA) content. Leaf anatomy was also analyzed to distinguish accumulation and translocation of oil compounds into leaf tissues. After 30 days of treatments, Rhizophora sp. had the highest viability and was able to reduce the higher level of TPH in the media compared to those of Avicennia sp. and Bruguiera sp. Petroleum hydrocarbon treatment caused the decrease of shoot and root growth of all species, as well as $\mathrm{pH}$ of the media, while it significantly increased malondialdehyde of the roots. Anatomical data showed that petroleum hydrocarbon was absorbed and translocated into the guard cell of the stomata. The result shows that Rhizophora sp. was the most tolerant mangrove species to petroleum hydrocarbon compared to Avicennia sp. and Bruguiera sp., indicated by its survival, the decrease of petroleum hydrocarbon in the sediment, and lower MDA content.
\end{abstract}

Keywords: Malondialdehyde, mangrove, oil contaminant, phytoremediation, Rhizophora, total petroleum hydrocarbon

\section{INTRODUCTION}

Riau Province, Indonesia has mangrove forest area more than 120,000 ha (BPS 2016), where 14062.50 ha are in Dumai City (BPS 2013). The area of the forest had been declining for a long time due to human activities around the forest. The data presented by research team of Yayasan Laksamana Samudera for example, showed that within 4 years (1998-2002) mangrove forest in Dumai had been lost more than 471 ha, which was similar to a decrease of 7.99 percent (PAB 2014). This decrease might be caused by human activities including oil industry activities around this area and even oil carrier crashed that may happened, which resulted in various environmental and economic losses and the decrease of carrying capacity of the natural resources around the city. Process of drilling and refining of oil sometimes also produces oil sludge, which is among the dangerous pollutants contaminating the surface of water in mangrove forest..

Among those pollutants, , petroleum hydrocarbon is one of the most common organic pollutant groups that is persistent in the environment, which is normally quantified with a common parameter known as Total Petroleum Hydrocarbon (TPH) (Suhardi 2014). Hydrocarbon derivatives such as gasoline, kerosene, paraffin, asphalt, and others are also commonly used by the community, risking spills to the environment. All of those conditions may have big impact on the surface layers, surface water and groundwater sources (Notodarmojo 2005; Cubillos et al. 2014). Therefore, some efforts to restore the coastal environment are urgently needed in order to maintain the ecological ecosystem balance.

Phytoremediation has been promoted as a potential method that becomes a better alternative due to its efficiency, affordability, and contribution to environmental safety (Espinosa et al. 2005). Phytoremediation is a part of biotechnology that utilizes physiological processes in plant body to increase the degradation and reduction of organic as well as inorganic contaminants from the soil, water and groundwater medium (EPA 2000). Phytoremediation may utilize various plants including grasses (Glick 2010), shrubs (Altinözlü et al. 2012), trees (Setyaningsih et al. 2007; He et al. 2013) as well as aquatic plants (Rai 2008; Sakakibara et al. 2011).

In Dumai, mangrove is one of important component in coastal ecosystems that often face environmental pollution derives from oil industry waste or even oil tanker accidents. In this area, mangrove plants have important role to improve the environment in coastal area, and therefore the plants can be used in phytoremediation program. Previous study suggested that some mangrove species such as Rhizophora sp. and Avicennia sp were able to be used in phytoremediation because they had absorbent characteristics and were not sensitive to the presence of TPH in the sediment (Moreira et al. 2011). The tolerance level of those species sometimes is associated with their capacity to adjust their structural and physiological changes in response to unfavorable environments. As an example, 
Diab and Bolus (2012) noted that the anatomy of Avicennia marina was changed due to the presence of oil pollutants stored in the leaf and plant roots. Other species may have different mechanism in response to pollutants. This study aimed to analyze the growth, anatomical and physiological responses of three mangrove species to petroleum hydrocarbon contaminant applied using ebb flow system to investigate the mechanism of tolerance and the prospect for phytoremediation.

\section{MATERIALS AND METHODS}

\section{Sediment and oil preparation}

Sediment that was used in this study was collected from the Mangrove Conservation Area of Bandar Bakau, Dumai City, Riau, Indonesia. Sediment samples were collected randomly from five sites. The samples were filtered and separated from rocks, and plant materials then mixed together in a plastic container to ensure uniformity. Oil pollutant that was used in this study was obtained from National Oil Company Pertamina Ltd. RU II Dumai.

\section{Procedures}

Mangrove seedling preparation

In this study, mangrove seedlings were prepared from the propagules obtained from the Conservation Area of Bandar Bakau Dumai. Three species of mangroves were used in the experiment, i.e., Rhizophora sp., Avicennia sp., and Bruguiera sp. Three months old seedlings were acclimatized for 1 week in the bioreactor before being treated with petroleum hydrocarbons.

\section{Experimental design}

This study was carried out using Completely Randomized Design with two factors, i.e., three mangrove plants (Rhizophora sp., Avicennia sp. and Bruguiera sp.) and four levels of petroleum concentration $(0 \%, 10 \%, 20 \%$ and $30 \%$ ) with 5 replications.

\section{Tidal bioreactor for planting}

Tidal bioreactor was designed to resemble the tidal conditions in mangrove ecosystem environment by applying the tidal hydroponic system (ebb flow system) with 2 times ebb and 2 times flow, each of which was running for 6 hours as shown in Figure 1.

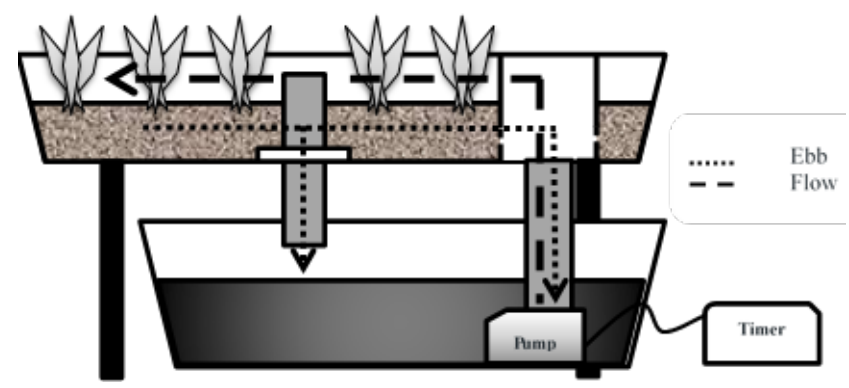

Figure 1. Design of tidal hydroponics bioreactor system (ebb flow system)

\section{Plant growth measurement}

Plant growth was observed by measuring plant height, the number of new roots and viability of the mangrove plant. Plant height was measured from the base of stem to the top of the shoot. Mangrove viability was calculated from the number of plants that were still alive after 30 days of treatment. Plant morphology including the changes of leaves color was also observed during the application with TPH treatments.

\section{TPHs Determination}

Total petroleum hydrocarbons (TPHs) in soil were determined using the EPA 418.1 method (EPA 2000). The grinded soil samples were weighed 5 grams in vials, then 2 $\mathrm{g}$ of sodium sulfate and $10 \mathrm{~mL}$ of TCE (Tetrachloroethylene) were added and stirred for 1 hour. Samples were allowed to stand for 1 minute to separate residues and solvents. The solvent layer was poured on a column that had been filled with $2 \mathrm{~g}$ of silica gel 70-230 mesh and then the absorbance of the solution was measured using IR spectrophotometer HC-404. The absorbance was recorded and the solution was diluted if the absorbance was more than 2.00. The TPH value was calculated as follow:

$$
T P H=C x f p T P H=\% T P H \times 10000
$$

Where:

$\mathrm{C}$ is the measured level $(\mathrm{mg} / \mathrm{L})$

$\mathrm{fp}$ is the dilution factor

\section{PH measurement}

The $\mathrm{pH}$ measurements of the medium were carried out using a digital $\mathrm{pH}$ meter at the beginning and the end of the experiment. Calibration was carried out using a buffer solution at $\mathrm{pH} 4$ and 7 . The changes of $\mathrm{pH}$ value were calculated from the initial $\mathrm{pH}$ minus the final $\mathrm{pH}$ of the study.

\section{Lipid peroxidation analysis}

Malondialdehyde (MDA) level is a common parameter to evaluate lipid peroxidation in membranes and biological systems, as well as indicators of free-radical formation in plant tissues (Halliwell and Chirico 1993). Lipid peroxidation was calculated by measuring the level of MDA using the method described by (Meriga et al. 2010). The $0.3 \mathrm{~g}$ of roots were weighed and homogenized with mortar, after which $5 \mathrm{ml}$ of $0.1 \%$ TCA was added and centrifuged at $10000 \times \mathrm{G}$ for $5 \mathrm{~min}$. After centrifugation, 1 $\mathrm{ml}$ of supernatant was mixed with $4 \mathrm{ml}$ of $0.1 \%$ thiobarbituric acid in $20 \%$ TCA, and the mixture was incubated in boiling water for $30 \mathrm{~min}$. Absorbance was measured using a spectrophotometer (Genesys Thermospectronic, USA) at $532 \mathrm{~nm}$ wavelength and adjusted for non-specific absorbance at $600 \mathrm{~nm}$. The difference in absorbance at both wavelengths is the value of MDA concentration as the lipid peroxidation end product. The MDA content was estimated by using the 155 (mmol/L/cm) extinction coefficient. 


\section{Histochemical analysis of leaves and roots tissues}

Preparation of leaf paradermal tissues was carried out by scraping adaxial parts of the leaves to get the abaxial samples. The preparation of leaf and roots transversal section was carried out by cutting leaves and roots using a frozen microtome (Yamato RV-240) with a thickness of $17-20 \mu \mathrm{m}$. The leaf sections were immersed to $70 \%$ ethanol for $1 \mathrm{~min}$ then stained in filtered solutions of Sudan IV in $70 \%$ ethanol for $30 \mathrm{~min}$ at $40^{\circ} \mathrm{C}$ in water bath, and washed rapidly with $70 \%$ ethanol (Boix et al. 2011). The section was placed in the object glass and closed by cover glass after added by glycerin. Samples were examined, and the photograph was taken using a light microscope camera (Olympus CX23 Microscope).

\section{Data analysis}

All quantitative data were analyzed using SPSS 22.0 to examined Analysis of Variance (ANOVA), followed by further analysis using Duncan's New Multiple Range Test (DNMRT) at $\alpha=5 \%$ to verify the response of mangrove species to petroleum treatment.

\section{RESULTS AND DISCUSSION}

\section{Plant viability and TPH of the media}

Petroleum treatment applied using tidal bioreactor significantly reduced plant growth and viability or survival depending on mangrove species and TPH concentration. The data related to the response of these plants and TPH concentration in the media is presented in Table 1. After 30 days of petroleum treatment, Rhizophora sp. had the highest survival rate which reached $100 \%$ followed by Bruguiera sp. and Avicennia sp., that was $65 \%$ and $60 \%$, respectively (Table 1). The treatment of oil in the media with various concentrations did not affect the survival rate of Rhizophora sp.; while, it decreased that of the others significantly even until $20 \%$ for Avicennia sp. (Table 1), suggesting that Rhizophora sp. was more resistant and adaptable to oil pollutant in the media than the other two species. Some chlorotic symptoms were observed on the leaves of Bruguiera sp. and Avicennia sp, which led to the death of some sample plants before 30 days. All the remaining plants that survive were able to grow well after experiment when they were transplanted to the normal media.

The observation of the media after 30 days of the treatment showed that residual TPH content in the media was varied depending on mangrove species. The lowest residual TPH was found in Rhizophora sp. (15.65 ppm) followed by Avicennia sp. and Bruguiera sp., i.e., 26.98 ppm and 32.44 ppm, respectively (Figure 2). This indicated that Rhizophora sp. had the ability to reduce TPH content of the media more than the other two species. Higher reduction of TPH content in the media of Rhizophora sp. confirmed the ability of the species to reduce hydrocarbon contaminant from its environment (Figure 2).

\section{The growth of mangrove}

The response of mangrove to TPH treatments was also observed by measuring parameters of growth, including the increase of plant height and the number of new roots appeared during the treatment. The decrease of plant growth calculated from plant height was occurred in the three species of mangrove in response to petroleum concentration where Avicennia sp. had the largest reduction at $30 \%$ petroleum concentration (Figure 3). Rhizophora sp. had the lowest growth rate compared to the other two species, while the growth of Bruguiera sp. was average. Different from Rhizophora sp. and Avicennia sp., growth reduction of Bruguiera sp. was not significantly different as compared to that of control plants ( $0 \%$ of petroleum) in response to petroleum treatment up to $30 \%$ concentration (Figure 3).

Table 1. Effect of treatment of petroleum concentration on viability of 3 mangrove plants

\begin{tabular}{ccccc}
\hline $\begin{array}{c}\text { Oil } \\
\text { treatment } \\
(\%)\end{array}$ & \multicolumn{4}{c}{ Plant viability (\%) } \\
\hline 0 & $100 \mathrm{a}$ & $100 \mathrm{a}$ & $100 \mathrm{a}$ & 100.0 \\
10 & $100 \mathrm{a}$ & $60 \mathrm{~b}$ & $60 \mathrm{~b}$ & 73.3 \\
20 & $100 \mathrm{a}$ & $60 \mathrm{~b}$ & $60 \mathrm{~b}$ & 73.3 \\
30 & $100 \mathrm{a}$ & $20 \mathrm{~d}$ & $40 \mathrm{c}$ & 53.3 \\
Average & 100 & 60 & 65 & 75 \\
\hline
\end{tabular}

Note: The number followed by similar letter does not significantly different based on Duncan Analysis at $5 \%$ of $\alpha$

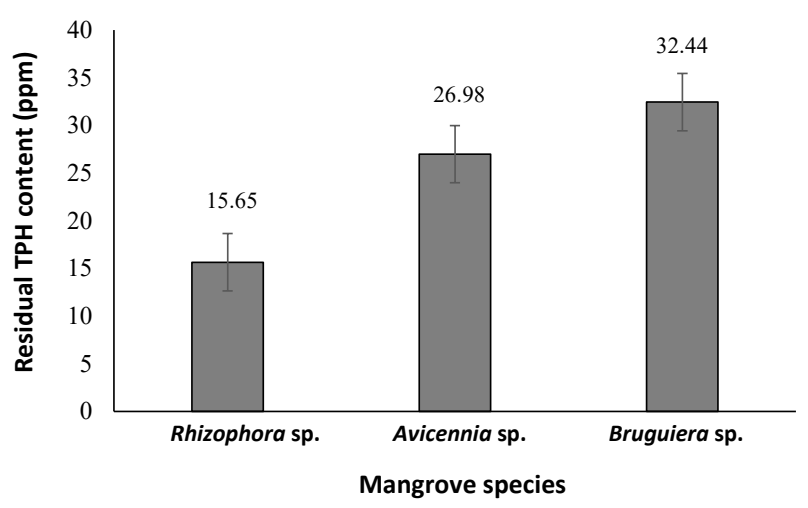

Figure 2. The residue of TPH observed from the media grown by 3 mangrove species after 30 days treatment

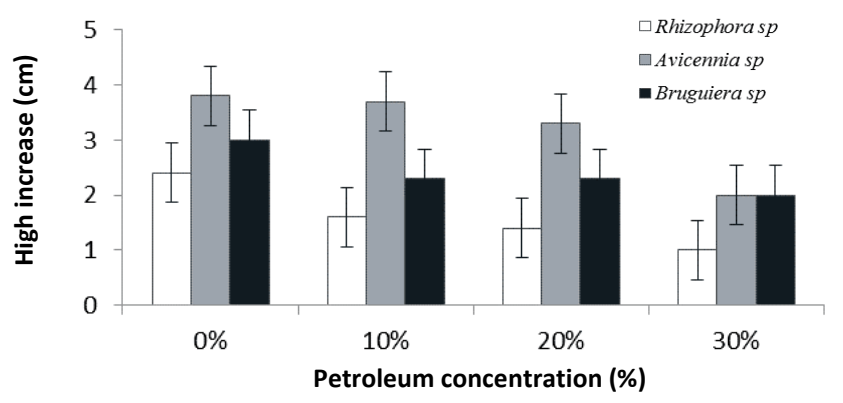

Figure 3. The increase of plant height after 30 days of petroleum treatment 
Petroleum treatment not only affected the shoot growth, but also involved in the emergence of new roots, the important organs required to absorb water and nutrients. The result showed that there was a decrease in the number of new roots that emerged after 30 days of petroleum treatment (Figure 4). Rhizophora sp. and Avicennia sp. had relatively equal number of new roots at control level, but in the TPH treatment, Rhizophora sp. had more new roots than Avicennia sp. The number of new roots in Bruguiera sp. was less than in Rhizophora sp. and Avicennia sp., both in the control and petroleum treatments. Bruguiera sp. had the slowest root growth compared to the others, but the decrease of root growth was not significantly different in response to petroleum treatments. Based on the data of shoot and root growth, it can be seen that petroleum treatment had a varied influence in mangrove growth, where the roots were more sensitive to the presence of petroleum hydrocarbon compounds compared to the shoots.

\section{The changes of $\mathrm{pH}$ of planting medium}

In general, petroleum treatment during 30 days decreased $\mathrm{pH}$ of the media. The decrease of $\mathrm{pH}$ occurred in all mangrove species treated with different petroleum concentrations. The decrease of $\mathrm{pH}$ medium in treated plants was higher than that in the control plants, except in Avicennia sp. In Rhizophora sp. and Bruguiera sp. the $\mathrm{pH}$ of the media treated with petroleum was more acidic than the control media, where the higher concentration of petroleum tended to reduce $\mathrm{pH}$ of the mangrove medium more (Table 2).

\section{Lipid peroxidation analysis}

The negative effect of petroleum treatment was also observed, indicated by the increase of malondialdehyde (MDA) content in the root tissues of all mangrove species which suggested the occurrence of lipid peroxidation. The increase of MDA levels occurred in line with the increase of petroleum concentration observed in all mangrove species. The increase of MDA levels in the roots indicated that the plants underwent stress due to the petroleum treatment. Three species of mangroves showed different responses to the petroleum treatment; the content of MDA in the roots of Rhizophora sp. was lower than that of Avicennia sp. and Bruguiera sp. under all petroleum treatments. The MDA of Bruguiera sp. was the highest among the three species in almost all treatments (Figure 5).

\section{Histochemical analysis of leaves and roots tissues}

Anatomical analysis of mangrove leaves was carried out to observe the absorption, distribution and accumulation of hydrocarbon compounds into the plant tissues especially in the leaf tissues, including stomata. The accumulation of petroleum hydrocarbon compounds in all mangrove species was found in roots and leaves. The observation of paradermal tissues using Sudan IV solution showed that petroleum accumulation was occurred in mangrove leaves. The accumulation of petroleum was observed in adaxial as well as abaxial of epidermal leaves of all mangrove species, which was marked by the appearance of yellowish-orange to red color in the object (Figures 6 and 7). The accumulation of petroleum inside the leaves was clearly observed in the stomata of Rhizophora sp. and Bruguiera sp., while for Avicennia sp., the accumulation of petroleum in the stomata was not clearly visible because it was covered by heavy trichome on the leaf surface (Figure 6.H). Petroleum treatment also affected the color of trichome in Avicennia sp. in which the trichome of control plant was brighter compared to the mangroves treated with petroleum which had darker color (Figures 6.F and $\mathrm{H}$ ).

Table 2. Effect of treatment of petroleum concentration on sediment $\mathrm{pH}$ reduction after 30 days

\begin{tabular}{lclll}
\hline $\begin{array}{l}\text { Mangrove } \\
\text { species } \square\end{array}$ & $\begin{array}{c}\text { Concentration } \\
(\%)\end{array}$ & $\begin{array}{l}\mathbf{p H} \\
\text { Before }\end{array}$ & $\begin{array}{l}\mathbf{p H} \\
\mathbf{A f t e r}\end{array}$ & $\begin{array}{l}\mathbf{p H} \\
\text { Reduction }\end{array}$ \\
\hline Rhizophora & 0 & $5.85 \mathrm{a}$ & $5.67 \mathrm{a}$ & $0.18 \mathrm{c}$ \\
sp. & 10 & $5.45 \mathrm{a}$ & $4.65 \mathrm{~b}$ & $0.80 \mathrm{ab}$ \\
& 20 & $5.36 \mathrm{ab}$ & $4.51 \mathrm{bc}$ & $0.85 \mathrm{a}$ \\
& 30 & $5.26 \mathrm{ab}$ & $4.30 \mathrm{c}$ & $0.96 \mathrm{a}$ \\
& & & & \\
Avicennia & 0 & $5.10 \mathrm{ab}$ & $4.80 \mathrm{~b}$ & $0.30 \mathrm{c}$ \\
sp. & 10 & $4.95 \mathrm{~b}$ & $4.70 \mathrm{~b}$ & $0.25 \mathrm{c}$ \\
& 20 & $4.93 \mathrm{~b}$ & $4.67 \mathrm{~b}$ & $0.26 \mathrm{c}$ \\
& 30 & $4.86 \mathrm{~b}$ & $4.59 \mathrm{~b}$ & $0.27 \mathrm{c}$ \\
Bruguiera & 0 & & & \\
sp. & 10 & $5.72 \mathrm{a}$ & $5.51 \mathrm{a}$ & $0.21 \mathrm{c}$ \\
& 20 & $5.56 \mathrm{a}$ & $4.95 \mathrm{~b}$ & $0.63 \mathrm{~b}$ \\
& 30 & $5.38 \mathrm{ab}$ & $4.69 \mathrm{~b}$ & $0.69 \mathrm{~b}$ \\
& & $0.69 \mathrm{~b}$ \\
\hline
\end{tabular}

Note: The number in the similar column followed by similar letter does not significantly different based on Duncan Analysis at 5\% of $\alpha$

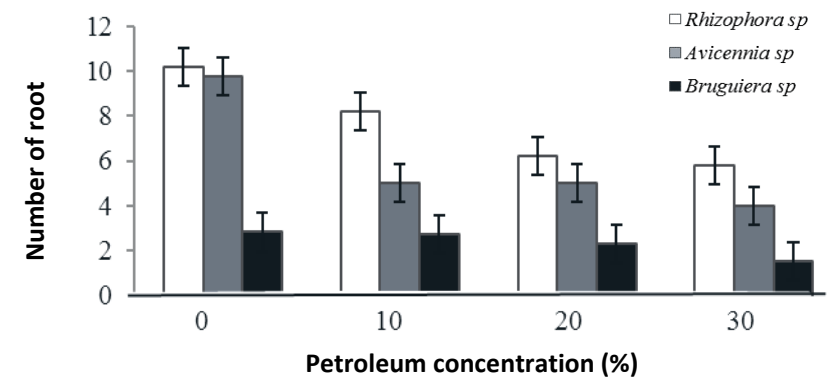

Figure 4. The number of new roots that appear on mangrove plants after 30 days of petroleum treatment

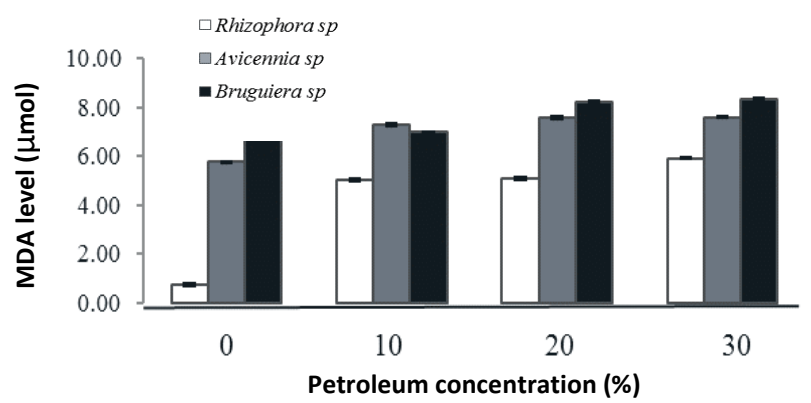

Figure 5. Effect of petroleum concentration treatment on MDA level on root of mangrove plant 


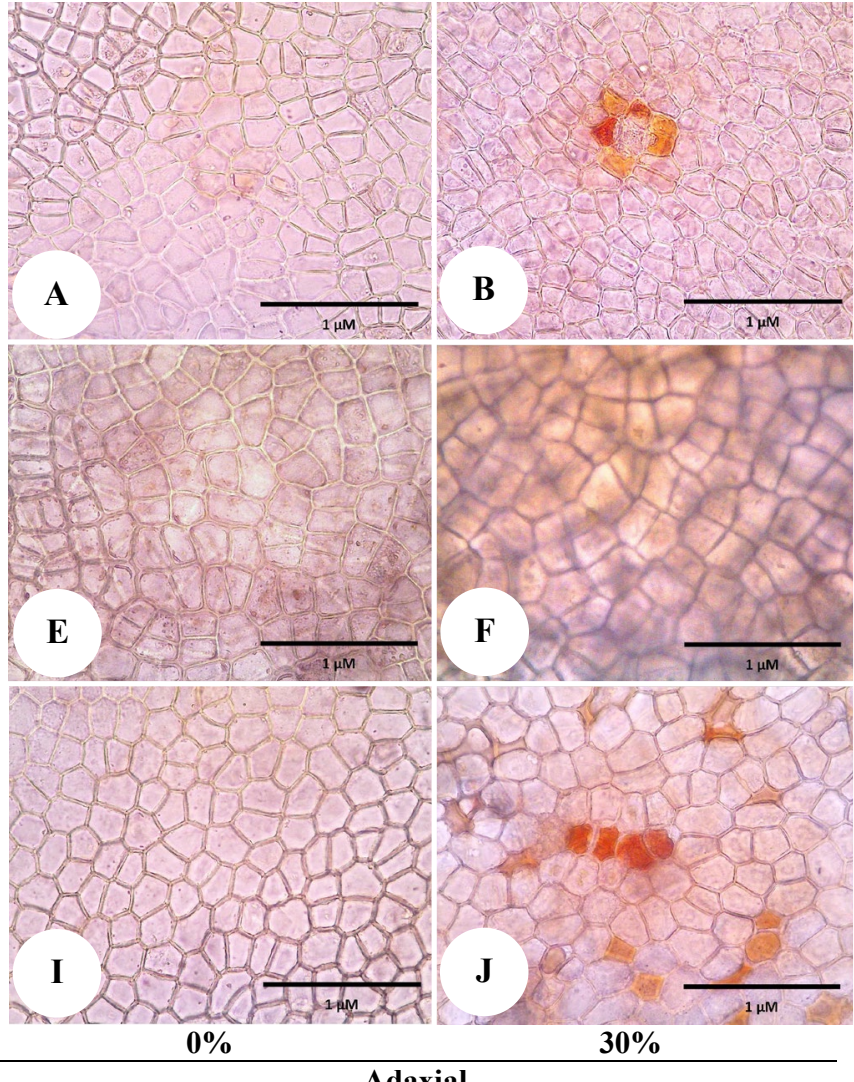

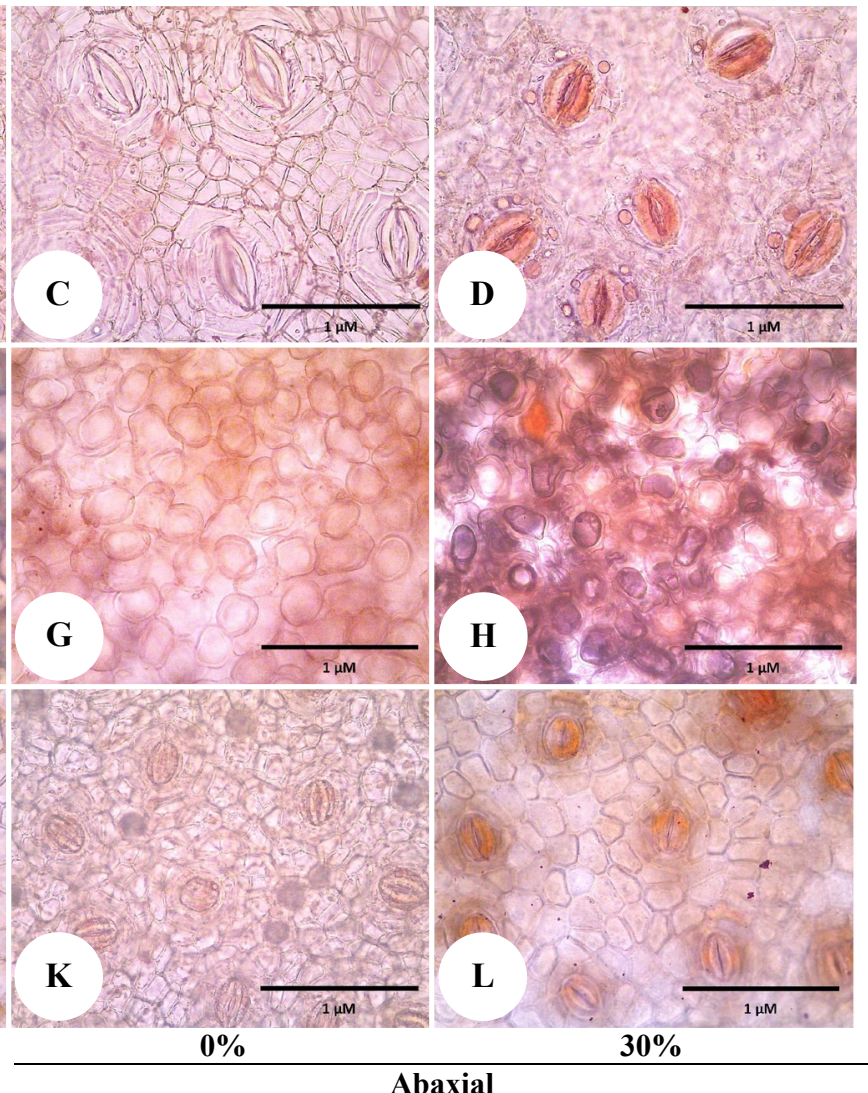

Figure 6. Paradermal observation of mangrove leaves. Rhizophora sp. (A, B, C, and D), Avicennia sp. (E, F, G and H) and Bruguiera sp. (I, J, K and L)

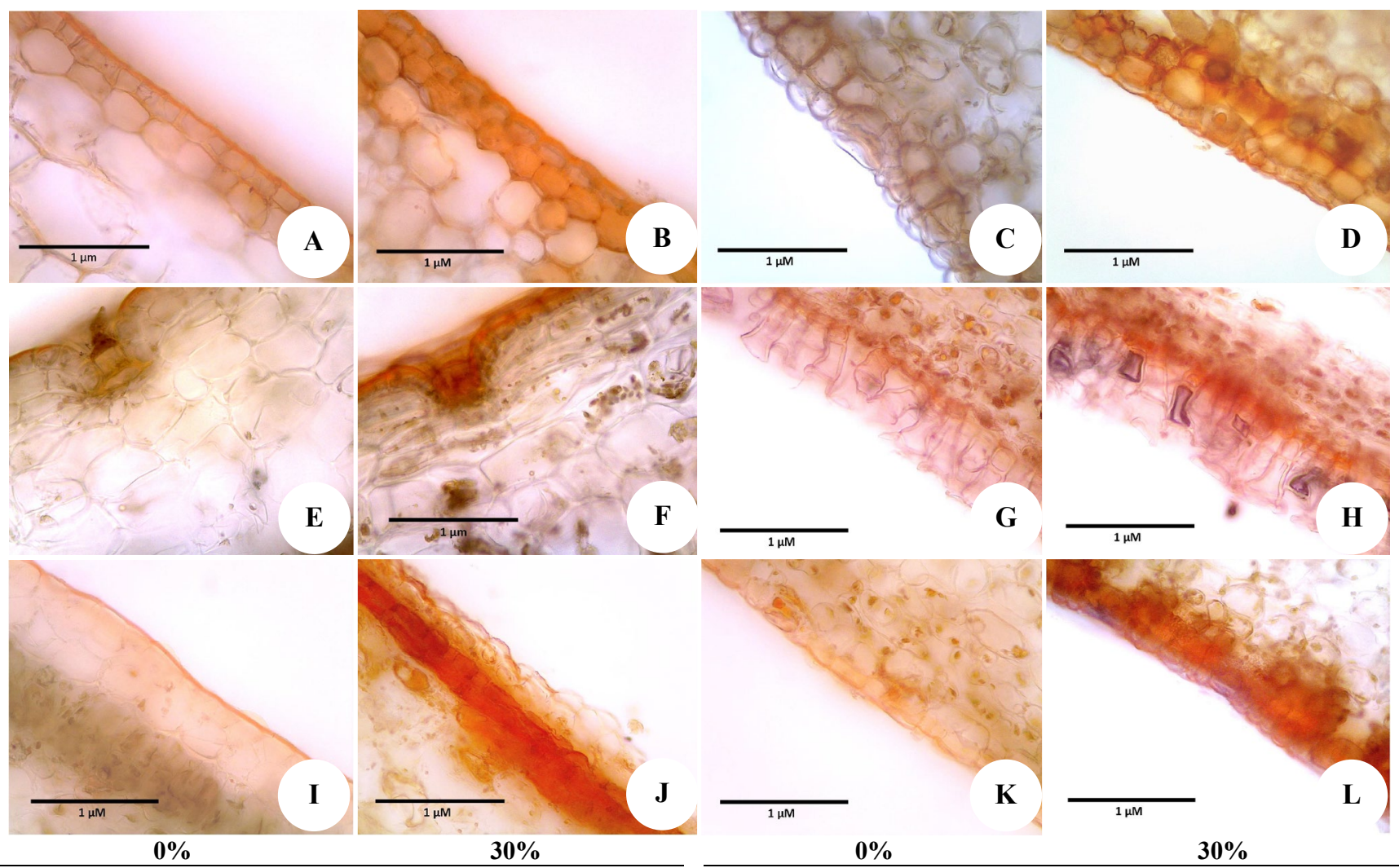

\section{Adaxial}

\section{Abaxial}

Figure 7. Transversal observation of mangrove leaves. Rhizophora sp. (A, B, C, and D), Avicennia sp. (E, F, G and H) and Bruguiera sp. (I, J, K and L) 


\section{Discussion}

The presence of hydrocarbon compounds in the media applied using tidal bioreactor caused disturbances to the mangrove plants, which was observed by the decrease of survived mangrove or mangrove viability after petroleum treatment. The higher viability revealed the better tolerance level of mangrove in response to TPH contaminant, as indicated by Rhizophora sp. (Table 1). The decrease of viability indicated the mortality rate of mangrove 1 month after exposure to petroleum treatment. The mortality of some mangrove species can also be observed by the presence of chlorosis and necrosis symptom, which leads to leaf abscission and even plant death (Data not shown). Symptoms of mangrove mortality such as leaf loss, drying bark and the appearance of fungi or bacteria was previously observed by other researchers (Pakpahan 1993). The chlorosis symptom occurred due to the increase concentration of petroleum hydrocarbon compounds taken up by roots and accumulated inside the leaf. Chlorophyll damage and photosynthesis inhibition was also observed in mangrove treated by petroleum, which led to leaf abscission (Naidoo et al. 2010). Symptoms of the damage appeared on the tip and root meristem which interfered with the function of the roots, whereas in the leave they occurred via dilation and distortion of the chloroplast (Naidoo and Naidoo 2016).

The presence of petroleum hydrocarbon compounds in plant tissues also caused a significant increase of MDA level in the roots, which caused major damage to plant tissues (Figure 5). The levels of MDA indicated the formation of ROS in the plant tissue and lipid peroxidation activity in the membrane (Halliwell and Chirico 1993). The increased oxidative compounds due to hydrocarbon contaminant can interfere with carbon metabolism in the leaves, decrease root respiration and disrupt the water and ion relationships so that the plant growth becomes disrupted (Proffitt et al. 1995; Parida et al. 2004). Even though the values varied among the three species, the increase of MDA levels was associated to the increase of petroleum concentration in all mangrove species, suggesting that the plants underwent stress due to the treatment. Excessive hydrocarbon compound taken up by the canopy probably induced the formation of oxidative reactions that were toxic and harmful to the cell, which inhibited growth of the canopy as well as the roots. Many evidences have been presented that hydrocarbon compounds in plants can induce ROS and will rapidly damage cells as well as biomolecules in plant bodies such as proteins, lipids and nucleic acids (Acworth and Bailey 1995). Odjegba and Badejo (2013) also reported the increase of MDA levels in Rhizophora mangle in response to petroleum treatment with the concentration of $1 \%, 3 \%$ and 5\% compared to control. The increase of ROS in plants is a general symptom of the plant's response to many environmental stresses such as drought, salinity, temperature, as well as hydrocarbon and heavy metal contaminants (Apel and Hirt 2004; Savicka and Skute 2010; Hamim et al. 2017a,b). In general, there was an increase in MDA level of the root for all species, but Rhizophora sp. had the lowest MDA contents compared to
Avicennia sp. and Bruguiera sp. (Figure 5) which indicated that Rhizophora sp. was more tolerant than the other two species to hydrocarbon contaminant.

The differences of TPH content in the media at the end of the treatment indicated a different absorption ability and degradation of hydrocarbon compounds facilitated by mangrove plants as a function of phytoremediation. The lower residual TPH content in the media of Rhizophora sp. indicated that this species had ability to absorb and/or accelerate the degradation of TPH content from the media more than other species (Figure 1). This result is in accordance with Titiresmi and Handayani (2012), who found that the decrease of TPH content of the media occurred after 6 weeks of petroleum treatment in Rhizophora mucronata. Moreira et al. (2011) also suggested that Rhizophora mangle was more efficient in degrading different fractions of petroleum hydrocarbons and reducing the TPH content of the media compared to other plants.

The presence of petroleum hydrocarbon compounds also caused a decrease of $\mathrm{pH}$ in the media (Table 2). The decrease of $\mathrm{pH}$ in the media might be caused by two factors: the secretion of organic acids by plants and the presence of compounds resulted from petroleum hydrocarbon degradation. A drastic $\mathrm{pH}$ decrease observed in the media of Rhizophora sp. due to the treatments might be associated with the secretion of acidic compounds or hydrocarbon degradation facilitated by this species. Pertiwi et al. (2013) noted that the degradation of hydrocarbon compounds produced several acidic compounds such as organic acids, methane, $\mathrm{H}_{2} \mathrm{O}$, and $\mathrm{CO}_{2}$.

The presence of hydrocarbon compounds in the leaf tissue was clearly observed in the abaxial and adaxial of epidermal leaves, characterized by the appearance of a yellowish-orange to red color (Figures 6 and 7), suggesting that the hydrocarbon was translocated and accumulated into the leaves. For more specific, the accumulation of petroleum hydrocarbon compounds was clearly observed in guard cells of the stomata (Figure 6). This supports the assumption that petroleum hydrocarbon compounds were absorbed into the plant body and transferred to the leaf tissues and stomata in line with transpiration process. Farias et al. (2008) also found that the toxic component of the major crude oil entered the plant body through roots, followed by the stems and was accumulated in the leaf of Avicennia marina. Lotfinasabasl et al. (2013) also stated that high TPH concentration of the leaves indicating high petroleum hydrocarbon uptake capability by leaves of the Avicennia marina. Furthermore, the experiment also found that in abaxial leaf of Avicennia sp., the trichome color became darker after treated with petroleum, which indicated that TPH was probably deposited in this organ (Figure 6). The color changes in trichome of Avicennia sp. and stomatal guard cells of Rhizophora sp. and Bruguiera sp. indicated that the petroleum hydrocarbon compound was absorbed by the roots and translocated or transported to the air through stomata guard cells and excreted through the trichome. In line with this, Diab and Bolus (2012) also found that petroleum treatment in Avicennia marina caused a dark color of the leaf trichome, which was assumed due to the deposition of certain foreign material into the plants. 
The same symptom was also found in Salvinia molesta, which also showed the dark-colored of leaf trachoma, possibly due to the accumulation of petroleum in the trichome (Pertiwi et al. 2013). Based on the parameters of leaf and root growth, plant viability, and MDA content, as well as visual symptoms, we concluded that Rhizophora sp. is more tolerant and adaptable to petroleum hydrocarbon contamination than Bruguiera sp. and Avicennia sp. and be able to be used for phytoremediation of petroleum hydrocarbon.

In conclusion, the treatment of petroleum hydrocarbons applied to mangrove plants in the tidal bioreactor system for 30 days led to a decrease in the growth of shoots and roots, and the $\mathrm{pH}$ of the media while it caused an increase of malondialdehyde (MDA) of mangrove roots. Rhizophora sp. had higher viability and was able to reduce TPH content of the media more than Avicennia sp. and Bruguiera sp. Anatomical data indicated that petroleum hydrocarbons were absorbed and translocated to the leaves and observed in guard cells of the stomata. Rhizophora sp. is the most tolerant species compared to Avicennia sp. and Bruguiera sp. characterized by their level of resistance to petroleum treatment, the lower MDA content of the root and its higher ability to reduce petroleum hydrocarbons in the sediment.

\section{ACKNOWLEDGEMENTS}

This research is funded by The Indonesia Endowment Fund for Education (LPDP) through the Indonesian Education Scholarship of Internal Master Program.

\section{REFERENCES}

Acworth IN, Bailey B. 1995. The Handbook of Oxidative Metabolism. ESA Inc, Chelmsford, MA, USA.

Altinözlü H, Karagöz A, Polat T, Ünver_I. 2012. Nickel hyperaccumulation by natural plants in Turkish serpentine soils. Turk J Bot 36: 269-280.

Appel K, Hirt H. 2004. Reactive oxygen species: metabolism, oxidative stress, and signal transduction. Annu Rev Plant Biol 55: 373-399.

BPS. 2013. BPS of Dumai Municipality: Dumai in Figure. Central Bureau of Statistics, Dumai. [Indonesian]

BPS. 2016. BPS-Statistics of Riau Province 2016. Riau Province in Figure. Riau. Central Bureau of Statistics, Riau. [Indonesian]

Boix YF, Victoria CP, Defaveri ACA, Arruda RCO, Sato A, Lage CLS. 2011. Glandular trichomes of Rosmarinus officinalis anatomical and phytochemical analyses of leaf volatiles. Plant Biosyst 145: 848-856.

Cubillos J, Pulgarin P, Gutierrez J, Paredes D. 2014. Phytoremediation of water and soils contaminated by petroleum hydrocarbons. Ingeniería y Competitividad 16 (1): 131-146.

Diab EA and Bolus ST. 2012. The effect of petroleum pollutans on the anatomical features of Avicennia marina (Forssk.) Vierh. Int J Sci Res. 2319-7064.

Dicks B. 1986. Oil and the black mngrove Avicennia marina in the Nothern Red Sea. Mar Pollut Bull 7: 500-503.

EPA [Enviromental Protection Agency]. 2000. Introduction to Phytoremediation. US Environmental Protection Agency, Washington DC.

Espinosa EE, Martınez MEG, Torres EF, Rojas MG. 2005. Improvemen of the hydrocarbon phytoremediation rate by Cyperus laxus Lam. inoculated with a microbial consortium in a model system. Chemosphere. 59: 405-413.

Farrias CO, Hamacher C, Wagener ADLR, Scofield ADL. 2008. Origin and degradation of hydrocarbon in mangrove sediments (Rio de Janeiro, Brazil) contaminated by an oil spill. Org Geochem 39: 289-307.
Glick BR. 2010. Using soil bacteria to facilitate phytoremediation. Biotechnol Adv. 28: 367-374.

Halliwell B, Chirico S. 1993. Lipid peroxidation: its mechanism, measurement and significance. Am J Clin Nutr 57: 715-725.

Hamim H, Hilmi M, Pranowo D, Saprudin D, Setyaningsih L. 2017a. Morpho-physiological changes of biodiesel producer plants Reutealis trisperma [Blanco] in response to gold-mining wastewater. Pakistan J Biol Sci 20: 423-435.

Hamim H, Violita V, Tridiarti T, Miftahuddin M. 2017b. Oxidative stress and photosynthesis reduction of cultivated (Glycine max L.) and wild soybean $(G$. tomentella $\mathrm{L}$.) exposed to drought and paraquat. Asian J Plant Sci 16 (2): 65-77.

He J, Ma C, Ma Y, Li H, Kang J, Liu T, Polle A, Peng C, Luo Z. 2013. Cadmium tolerance in six poplar species. Environ. Sci Pollut Res. 20: 163-174.

Lotfinasabasl S, Gunale VR, Rajurkar NS. 2013. Petroleum hydrocarbon pollution in soil and its bioaccumulation in mangrove species, Avicennia marina from Alibaug mangrove ecosystem, Maharashtra, India. Int J Adv Res Tech 2 (2): 1-7.

Meriga B, Attiyalla IH, Ramgopal M, Adiga A, Kavikishor PB. 2010. Differential tolerance to aluminum toxicity in rice cultivars: Involvent of antioxidative enzymes and possible role of aluminum resistant locus. Acad J Plant Sci 3 (2): 53-63.

Moreira ITA, Oliveira OMC, Triguis JA, Ana MP, Queiroz AFS, Martins CMS, Jesus RS. 2011. Phytoremediation using Rizophora mangle L. in mangrove sediments contaminated by persistent total petroleum hydrocarbons (TPH). Microchem J 99 (2): 376-382.

Naidoo G, Naidoo K. 2016. Uptake of polycyclic aromatic hydrocarbons and their cellular effects in the mangrove Bruguiera gymnorrhiza. Mar Pollut Bull 113: 193-199.

Naidoo G, Naidoo Y, Achar P. 2010. Responses of the mangroves Avicennia marina and Bruguiera gymnorrhiza to oil contamination. Flora. 205: 357-362.

Notodarmojo S. 2005. Soil \& Ground Water Pollution. Penerbit ITB, Bandung. [Indonesian]

Odjegba V J, Badejo J O. 2013. Crude oil induced oxidative stress in Capsicum annum L. Nat Sci 11 (2).

[PAB] Nature Nautical Lover. 2014. Lifting Potency of Mangrove Forest Tourism Tuo Kedondong Dumai Village. www.dumaiheadlines.com/Dumai-around-the-potential-tourismforest-mangrove-kampong-tuo-kedondong-dumai/.

Pakpahan AM. 1993. Damage and Efforts to Rehabilitate Mangrove Forest at Rambut Island Nature Reserve, Jakarta Bay. In the National Symposium on Rehabilitation and Conservation of Mangrove Area STIPER. Yogyakarta. [Indonesian]

Parida KA, Das AB, Mohanty P. 2004. Defense potentials to $\mathrm{NaCl}$ in a mangrove, Bruguiera parviflora: differential changes of isoform of some antioxidant enzymes. J Plant Physiol 161: 351-542.

Pertiwi SE, Juswardi, Yudoyono B, Nita FA. 2013. The phytoremediation ability of Salvinia molesta D. S. Mitchell on some concentrations of petroleum wastewater. J Penel Sains 16 (1): 27-32.

Pezeshki SR, Hester MW, Lin Q, Nyman JA. 2000. The effect of oil spill and clean up on dominants US Gulf coast marsh macrophytes: a review. Environ Pollut 8: 129-139.

Proffitt CE, Delvin DJ, Lindsey M. 1995. Effect of oil on mangrove seedling grown under different environmental condition. Mar Pollut Bull 30: 788-793.

Rai PK. 2008. Phytoremediation of $\mathrm{Hg}$ and $\mathrm{Cd}$ from industrial effluents using an aquatic free floating macrophyte Azolla pinnata. Intl J Phytorem 10: 430-439.

Sakakibara M, Ohmori Y, Ha NTH, Sano S, Sera K. 2011. Phytoremediation of heavy metal-contaminated water and sediment by Eleocharis acicularis. Clean-Soil Air Water 39: 735-741.

Savicka M, Skute N. 2010. Effects of high temperature on malondialdehyde content, superoxide production and growth changes in wheat seedlings (Triticum aestivum L.). Ekologija 56: 26-33.

Setyaningsih L, Setiadi Y, Budi SW, Hamim H, Sopandie D. 2017. Lead accumulation by jabon seedlings (Anthocephalus cadamba) on tailing media with application of compost and arbuscular mycorrhizal fungi. IOP Conf Series: Earth and Environ Sci 58: 012053. DOI: $10.1088 / 1755-1315 / 58 / 1 / 012053$

Suhardi R. 2014. Bioremediation and total petroleum hydrocarbon. Penerbit ITB, Bandung. [Indonesian]

Suprayogi B, Murray F. 1999. A field experiment of the physical and chemical effects of two oils on mangrove. Environ Exp Bot 42: 221229. 


\section{BIODIVERSITAS}

ISSN: 1412-033X

Volume 19, Number 3, May 2018

E-ISSN: 2085-4722

Pages: 786-792 